\title{
POTENSI EKONOMI PENGGUNAAN BAHAN BAKAR MINYAK (Studi Kasus Universitas Diponegoro)
}

\author{
Astiwi Indriani \\ Departemen Manajemen Fakultas Ekonomika dan Bisnis Universitas Diponegoro \\ Jl. Prof. Soedharto SH Tembalang, Semarang 50275, Phone : +622476486851
}

\begin{abstract}
This research want to investigate the economic potential of the use of fuel oil with research object at Diponegoro University. This research was conducted to know the potential of oil fuel usage in the campus area, the potential cost to fulfill the requirement of fuel oil and analyze the influence of the number of vehicle and the type of vehicle variable to the fuel consumption as well as the average difference of fuel consumption between the type of motorcycle and cars.

The analysis technique used is quantitative descriptive analysis to find out the potential use and cost of fuel oil; also used multiple linear regression analysis and t-test different to analyze average difference of fuel consumption between motorcycle and car.

The results of the analysis show that the potential use of fuel reaches 1987,7 liters for the nearest distance and 5331,5 liters for the furthest distance with potential cost of each reach 13 million rupiah and 35 million rupiah every 5 hours/week. Show that campus has a very high potential in the absorption of fuel. Then the percentage of vehicle users is mostly contributed by vehicles with vehicle code : $H(42 \%), B(10 \%)$, and $K(9 \%)$. The Results of multiple linear regression analysis with $t$ test showed that the number of vehicles and vehicle types variable partially have a significant positive effect on the use (consumption) of fuel. Adjusted R square value of $94.7 \%$ and the rest $5.3 \%$ is influenced by other factors. T-test different results indicate that there are differences in fuel consumption between types of motorcycle and cars.
\end{abstract}

Keywords: Number of vehicles, Type of Vehicle, Economic Potential of Fuel Oil Usage.

\section{Pendahuluan}

Anggaran subsidi Bahan Bakar Minyak atau BBM pada APBN di negara Indonesia dari tahun ke tahun semakin meningkat. Hal ini berdasarkan data yang diperoleh dari Biro analisa anggaran dan pelaksanaan APBN- Sekjen DPR RI menunjukkan bahwa subsidi BBM pada tahun 2010 sebesar 68,7 triliun rupiah, tahun 2011 sebesar 95,9 triliun rupiah dan tahun 2012 sebesar 123,6 triliun rupiah. Angka subsidi BBM yang terus naik membuat pemerintah kesulitan merealisasikan pembangunan secara maksimal. Data dari dari Biro analisa anggaran dan pelaksanaan APBN - Sekjen DPR RI juga menunjukkan bahwa persentase subsidi BBM terhadap jumlah total subsidi yang dibayarkan negara juga mengalami peningkatan. Pada tahun 2010 persentase subsidi BBM mencapai 33\% dari total subsidi, tahun 2011 mencapai 43\% dan tahun 2012 mencapai 55\%. Hal ini menjadi perhatian serius bagi kelangsungan masa depan bangsa.

Konsumsi BBM yang meningkat dari tahun ke tahun disebabkan adanya peningkatan jumlah kendaraan bermotor 
yang ada di Indonesia. Kota Semarang saat ini menjadi kota yang cukup padat dengan arus kendaraan bermotornya. Dari data statistik transportasi kota semarang (BPS,2009), menunjukkan bahwa terjadi peningkatan jumlah kendaraan bermotor. Sepeda motor tetap menjadi kendaraan dengan jumlah terbesar yaitu 115.051 unit tahun 2007; 123.527 unit tahun 2008 dan 119.016 unit tahun 2009, dibandingkan dengan jenis kendaraan lain seperti mobil pribadi sebesar 34.335 unit tahun 2007; 34.625 unit tahun 2008 dan 44.660 unit tahun 2009.

Universitas Diponegoro yang berlokasi di Kota Semarang dan seiring dengan optimalisasi fungsi kampus UNDIP di wilayah Tembalang akan meningkatkan penggunaan kendaraan bermotor oleh Civitas Akademika. Penggunaan kendaraan bermotor yang semakin masif oleh Civitas Akademika di Kampus Tembalang mendorong meningkatnya penggunaan BBM yang pada akhirnya ikut mendongkrak angka subsidi yang harus dibayarkan oleh negara. Kemacetan yang terjadi di kampus UNDIP Tembalang turut melipatgandakan konsumsi bahan bakar minyak. Hal ini menjadi dasar penelitian yang ingin menganalisis pengaruh variabel jumlah kendaraan dan jenis kendaraan terhadap konsumsi BBM dan mengetahui perbedaan rata-rata konsumsi BBM antara kendaraan motor dan mobil selain itu mengetahui potensi penggunaan BBM serta biaya yang dikeluarkan untuk memenuhi kebutuhan BBM.

\section{Tinjauan Pustaka dan Perumusan Hipotesis \\ Konsep Konsumsi BBM}

Departemen Perhubungan Darat (2008) menyatakan bahwa energi fosil adalah jenis energi yang tak terbarukan (unrenewable), jenis energi tersebut selama ini dikenal sebagai Bahan Bakar Minyak. Sementara ini, cadangan BBM terbatas sifatnya karena merupakan energi yang tak terbarukan, pada saatnya akan tidak dapat mencukupi kebutuhan atau bahkan habis sama sekali. Oleh karena itu perlu adanya penghematan konsumsi Bahan Bakar Minyak secara nasional terutama sektor transportasi darat. BBM merupakan suatu senyawa organik yang dibutuhkan dalam suatu pembakaran dengan tujuan untuk mendapatkan energi atau tenaga yang merupakan hasil dari proses distilasi minyak bumi (crude oil) menjadi fraksi-fraksi yang diinginkan. Jenis BBM antara lain : avgas, bensin premium, karosen, avtur, solar dan diesel serta minyak bakar (Handajani, 2011).

\section{Hubungan Jumlah dan Jenis Kendaraan terhadap Konsumsi BBM}

Konsumsi BBM dipengaruhi oleh tata guna lahan, jumlah penduduk, kepadatan penduduk, dan alat transportasi yang didalamnya terdapat panjang perjalanan, jumlah kendaraan, perilaku pengguna jalan, panjang jalan, dan kondisi jalan (Handajani, 2011). Keterkaitan antara jumlah kendaraan dengan konsumsi BBM juga diteliti oleh Suliyanti (2012) Kenworthy J., dan Fellix Laube (2002), Andry Tanara (2003), dan Dephubdat (2008) yang menyatakan bahwa semakin banyak kendaraan bermotor semakin besar konsumsi BBM. Dalam penggunaanBBM, aset bergerak (kendaraan bermotor) menjadi pengguna langsung BBM. Variabel jumlah kendaraan menjadi variabel utama yang digunakan dalam penelitian ini, dikarenakan sesuai dengan penelitian yang dilakukan oleh Handajani (2011) dimana variabel jumlah kendaraan 
(sepeda motor, mobil penumpang umum dan truk) berpengaruh kuat terhadap konsumsi BBM. Jenis kendaraan dalam penelitian ini dibagi menjadi roda dua (motor) dan roda empat (mobil). Sedangkan Handajani (2011) mengklasifikasikan jenis kendaraan yaitu kendaraan umum penumpang (MPU), Bus Umum, Angkutan barang (truk), dan kendaraan pribadi (mobil penumpang, bus, dan sepeda motor). Handajani (2011) menyatakan bahwa sistem transportasi (meliputi jenis kendaraan, panjang jalan, panjang trayek, jumlah kendaraan) memiliki hubungan yang kuat dengan konsumsi BBM. Oleh karena itu dalam penelitian ini untuk variabel jenis kendaraan hanya memfokuskan pada kendaraan pribadi (termasuk milik institusi UNDIP).

\section{Perumusan Hipotesis}

Dalam penelitian ini hipotesis yang diajukan adalah :

H1 : Jumlah kendaraan berpengaruh positif terhadap penggunaan BBM

$\mathrm{H} 2$ : Jenis kendaraan berpengaruh positif terhadap penggunaan $\mathrm{BBM}$

H3: Ada perbedaan pengaruh jenis kendaraan yaitu motor dan mobil dalam mempengaruhi penggunaan BBM

\section{Metode Penelitian}

Jenis data yang digunakan adalah data primer (primary data) yaitu berupa observasi langsung dilapangan. Populasi dalam penelitian ini adalah kendaraan bermotor yang melintasi pintu gerbang utama kampus Universitas Dionegoro tembalang pada tahun 2013 selama 5 hari Pk.06.30-07.30. Sampel diperoleh dengan menggunakan purposive sampling yaitu memilih sampel dengan kriteria tertentu, sehingga sesuai dengan penelitian yang dirancang. Variabel-variabel penelitian yang dibutuhkan dalam penelitian ini yaitu penggunaan (konsumsi) BBM sebagai variabel dependen dan variabel jumlah dan jenis kendaraan sebagai variabel independen.

$$
\text { Variabel Penggunaan (konsumsi) }
$$

BBM merupakan jumlah unit kendaraan (motor dan mobil) dikalikan dengan 0,1 liter untuk motor dan 0,3 liter pada jarak terdekat. Dan jumlah kendaraan (motor dan mobil) dikalikan 0,3 liter untuk motor dan 0,5 liter untuk mobil pada jarak terjauh. Variabel jumlah Kendaraan merupakan keseluruhan unit kendaraan baik itu motor dan mobil. Sedangkan variabel jenis kendaraan merupakan klasifikasi kendaraan menurut jumlah roda yaitu roda dua (motor) dan roda empat (mobil).

Analisis menggunakan regresi linier berganda dengan menggunakan uji asumsi klasik sedangkan analisis dengan uji beda t-test digunakan untuk mengetahui perbedaan rata-rata konsumsi BBM antara kendaraan motor dan mobil. Analisis regresi linier berganda dengan persamaan kuadrat terkecil (Ordinary Least Square$O L S$ ) dengan formula sebagai berikut :

$$
\mathrm{Y}=\mathrm{a}+\mathrm{b}_{1} \mathrm{X} 1+\mathrm{b}_{2} \mathrm{X} 2+\mathrm{e}
$$

Keterangan :

Y : Penggunaan (konsumsi) BBM untuk jarak terdekat dan jarak terjauh (dalam liter)

a : konstanta

$\mathrm{b}_{1}, \mathrm{~b}_{2} \quad$ : koefisien regresi masing masing variabel independen

X1 : Jumlah kendaraan (dalam unit)

X2 : Jenis Kendaraan (Motor kode 1 dan Mobil kode 2)

e :Variabel Residual 


\section{Pembahasan}

\section{Analisis Potensi Penggunaan (Konsumsi)} BBM

Dalam analisis potensi penggunaan (konsumsi) BBM, data kendaraan yang diperoleh dari observasi langsung dengan hasil berupa gambar dua dimensi dilakukan input data menggunakan program excel. Data diklasifikasikan menurut tanggal perekaman, waktu perekaman (running time), nomor plat kendaraan dan jenis kendaraan. Dari hasil penelitian didapatkan bahwa jumlah kendaraan civitas akademika Universitas Diponegoro yang melintas saat penelitian dilakukan adalah 15.719 kendaraan bermotor yang terdiri dari 15.140 unit motor dan 1.579 unit mobil. Dari data penelitian tersebut didapatkan bahwa mayoritas atau 90,56\% civitas akademika UNDIP menggunakan motor sebagai alat transportasi di lingkungan kampus UNDIP Tembalang dan 9,44 \% menggunakan mobil sebagai alat transportasi. Berikut grafik perbandingan kendaraan motor dan mobil dilingkungan civitas akademika UNDIP Tembalang.

Gambar 1

Perbandingan Kendaraan motor dan mobil

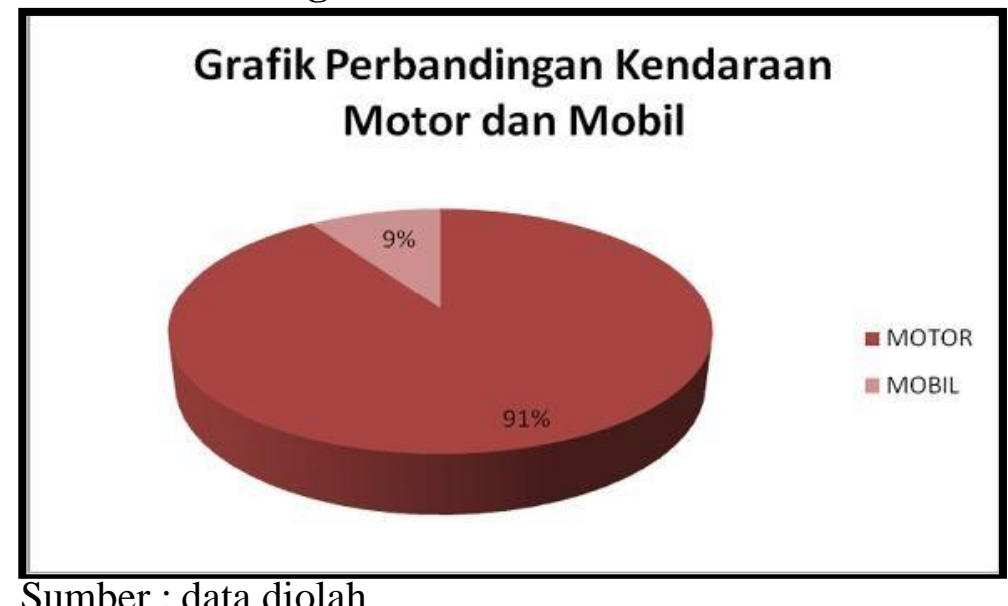

Sumber : data diolah

Dengan luasan kampus UNDIP Tembalang mencapai $1.352 .054 \mathrm{~m}^{2}$ dan jumlah kendaraan 16.719 maka dapat dihitung potensi penggunaan Bahan Bakar Minyak (BBM) di kampus UNDIP Tembalang yang diuraikan dalam Tabel 1 Potensi penggunaan BBM dibawah ini : 
Tabel 1

Potensi Penggunaan BBM

\begin{tabular}{|c|c|c|c|c|c|c|c|}
\hline \multirow{2}{*}{ Uraian } & \multirow{2}{*}{$\begin{array}{c}\text { Jumlah } \\
\text { Kendaraan } \\
\text { (Unit) }\end{array}$} & \multirow{2}{*}{$\begin{array}{c}\text { Jarak } \\
\text { Ter- } \\
\text { dekat } \\
\text { (liter) }\end{array}$} & \multirow{2}{*}{$\begin{array}{c}\text { Jarak } \\
\text { Ter- } \\
\text { jauh } \\
\text { (liter) }\end{array}$} & \multicolumn{2}{|c|}{$\begin{array}{c}\text { Potensi Jumlah } \\
\text { BBM yang } \\
\text { digunakan (liter) }\end{array}$} & \multicolumn{2}{|c|}{$\begin{array}{c}\text { Potensi Biaya BBM } \\
\text { yang dikeluarkan } \\
\text { (rupiah) }\end{array}$} \\
\hline & & & & $\begin{array}{c}\text { Jarak } \\
\text { Terdekat }\end{array}$ & $\begin{array}{c}\text { Jarak } \\
\text { Terjauh }\end{array}$ & $\begin{array}{c}\text { Jarak } \\
\text { Terdekat } \\
*\end{array}$ & $\begin{array}{c}\text { Jarak } \\
\text { Terjauh } *\end{array}$ \\
\hline Motor & 15.140 & 0,1 & 0,3 & 1514 & 4542 & 9.841 .000 & 29.523 .000 \\
\hline Mobil & 1.579 & 0,3 & 0,5 & 473,7 & 789,5 & 3.079 .050 & 5.131 .750 \\
\hline Jumlah & 16.719 & & & 1987,7 & 5331,5 & 12.920 .050 & 34.654 .750 \\
\hline
\end{tabular}

* harga BBM Rp. 6.500/liter (2013)

Sumber : data diolah

Dari tabel diatas menunjukkan hasil jumlah kendaraan baik itu motor (roda dua) dan mobil (roda empat) dengan jumlah 15.140 unit motor dan 1.579 unit mobil. Potensi jumlah BBM yang digunakan untuk jarak terdekat sebanyak 1987,7 liter dengan total potensi biaya yang dikeluarkan $\mathrm{Rp}$. 12.920.050. Sedangkan potensi jumlah BBM yang digunakan untuk jarak terjauh sebanyak 5331,5 liter dengan total potensi biaya yang dikeluarkan Rp. 34.654.750. Data ini menunjukkan bahwa jumlah kendaraan yang melintas di kampus Universitas Diponegoro tiap 5 jam per minggu memiliki jumlah yang fantastis dan kebutuhan BBM yang mencapai puluhan juta per 5 jam per minggu. Jika diproyeksikan selama satu bulan potensi jumlah BBM yang digunakan mencapai 8000 liter untuk jarak terdekat dan 21.000 liter untuk jarak terjauh dengan potensi

biaya 52 juta untuk jarak terdekat dan 136,5 juta untuk jarak terjauh. Proyeksi ini tentunya hanya meng-cover pengamatan satu jam per hari dengan lima hari pengamatan. Sedangkan civitas akademika akan melintasi pintu utama gerbang tidak hanya sekali dan aktivitas dapat dilakukan hingga sore hari. Data ini menunjukkan bahwa kampus menjadi magnet dan pusat peredaran uang yang luar biasa hanya dilihat dari potensi penggunaan BBM. Tentunya dengan jumlah kendaraan yang mencapai puluhan ribu per jam per hari menjadi peringatan bagi kampus karena dapat menimbulkan efek negatif yaitu kemacetan lalu lintas. Berikut ini akan disajikan pada gambar 2 dan 3 data jumlah dan prosentase kendaraan yang diklasifikasikan berdasarkan kode plat kendaraan tiap kota. 
Gambar 2

Perbandingan 10 Besar Jumlah Kendaraan Berdasarkan Kode Plat

\section{Perbandingan 10 Besar Jumlah Kendaraan berdasarkan KodePlat Tiap Kota}

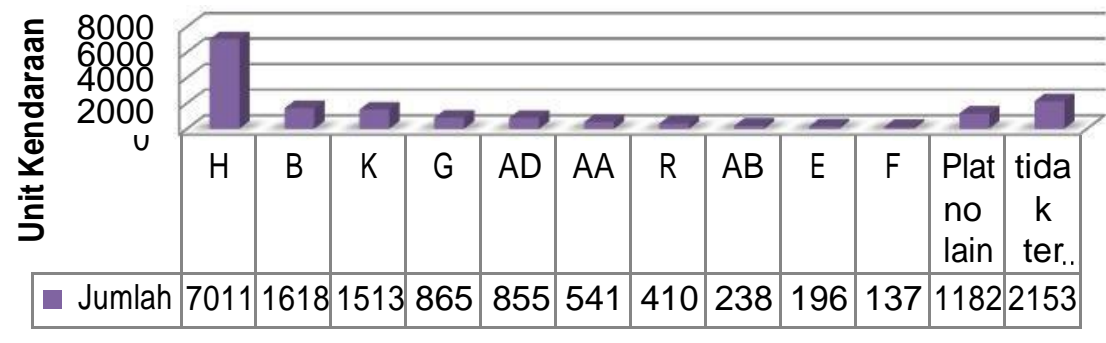

Sumber : data diolah

Gambar 3

Perbandingan 10 Besar Prosentase Kendaraan Berdasarkan Kode Plat

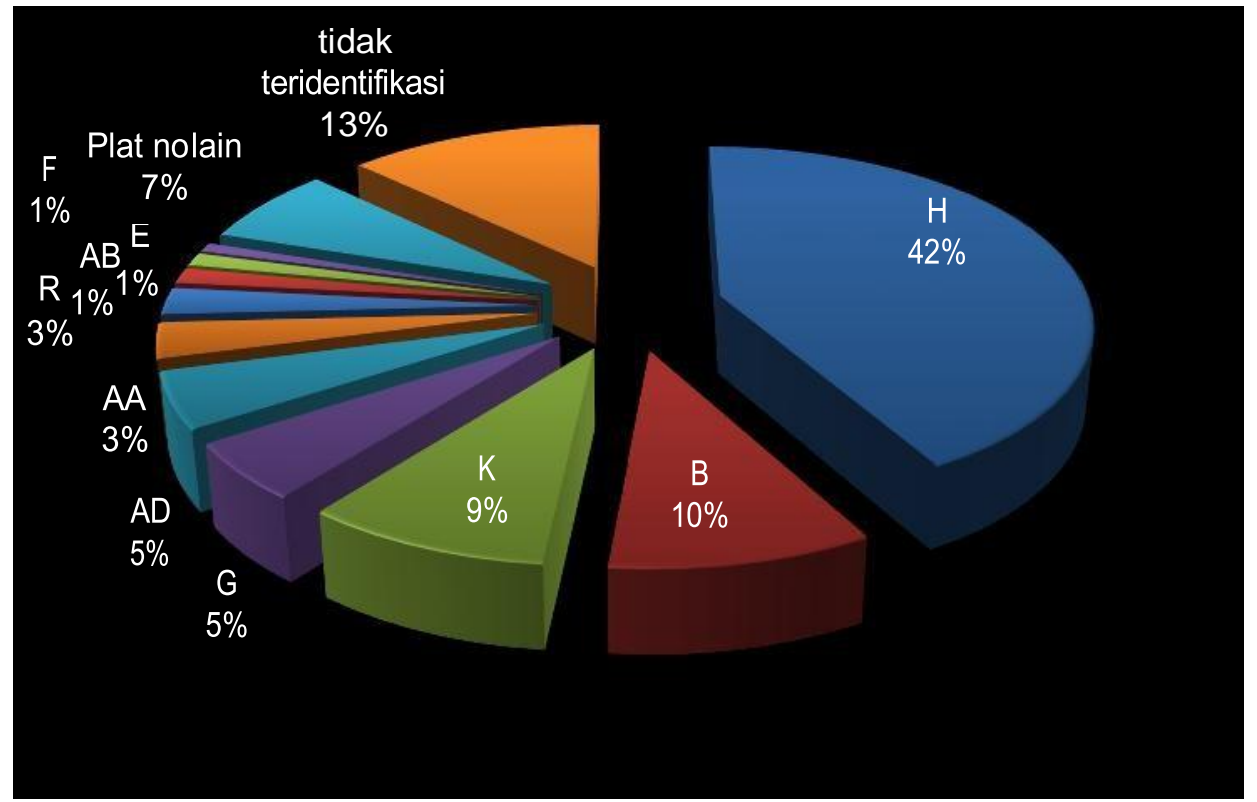

Sumber : Data diolah

Berdasarkan gambar 2 dan 3 diatas menunjukkan bahwa nomor platkendaraan tiap kota dengan kode $\mathrm{H}$ (Semarang dan sekitar) menduduki peringkat pertama dengan jumlah 7011 unit kendaraan dengan prosentase sebesar $42 \%$. Sedangkan peringkat kedua adalah Kode B
(Jakarta) dengan jumlah 1618 unit kendaraan atau $10 \%$. Kode Plat B ini mengalahkan kode plat $\mathrm{K}$ dengan 1513 unit kendaraan atau setara 9\%. Hal ini menunjukkan bahwa civitas akademika khususnya mahasiswa Universitas Diponegoro kebanyakan berasal dari 
Semarang dan Jakarta. Tingginya kode plat B dari Jakarta menunjukkan bahwa minat yang sangat tinggi bagi warga Jakarta untuk menyekolahkan anak-anak mereka di kota Semarang. Mengenyam pendidikan di Kota Semarang mulai diminati karena biaya kuliah di kota Semarang relatif lebih murah daripada Universitas di Jakarta dan sekitarnya. Banyaknya jumlah mahasiswa dari Jakarta dan kota-kota lain diluar Semarang tentunya akan menambah jumlah penggunaan (konsumsi) BBM di Semarang.

\section{Analisis Model Regresi Linier Berganda}

Model yang dikembangkan dalam penelitian ini telah lolos uji asumsi klasik baik normalitas, multikonearitas, autokorelasi dan heteroskedastisitas, sehingga model ini layak digunakan. Kemudian dari uji statistik F dibawah ini :

Tabel 2

Hasil Uji Statistik F

ANOVA $^{\text {b }}$

\begin{tabular}{|c|c|c|c|c|c|c|}
\hline Model & & Sum of Squares & $\mathrm{df}$ & Mean Square & $\mathrm{F}$ & Sig. \\
\hline \multirow[t]{3}{*}{1} & Regression & 6309.354 & 2 & 3154.677 & 883.763 & $.000^{\mathrm{a}}$ \\
\hline & Residual & 346.251 & 97 & 3.570 & & \\
\hline & Total & 6655.605 & 99 & & & \\
\hline
\end{tabular}

a. Predictors: (Constant), JENIS, UNIT

b. Dependent Variable: BBM1

Sumber : output SPSS

Dari hasil uji statistik $f$ diatas, didapat nilai f hitung adalah 883,763 dengan tingkat signifikansi 0,000. karena tingkat signifikansi lebih kecil dari 0,05, maka model regresi bisa dipakai untuk memprediksi BBM1 (jarak terdekat) atau dengan kata lain variabel unit kendaraan dan jenis kendaraan secara bersama-sama berpengaruh terhadap BBM1. Hasil uji statistik F untuk memprediksi BBM2 (jarak terjauh) juga memiliki hasil yang sama dengan BBM1.

\section{Tabel 3}

Hasil uji regresi linier berganda

Coefficients $^{a}$

\begin{tabular}{|c|c|c|c|c|c|c|}
\hline \multirow{2}{*}{\multicolumn{2}{|c|}{ Model }} & \multicolumn{2}{|c|}{$\begin{array}{l}\text { Unstandardized } \\
\text { Coefficients }\end{array}$} & \multirow{2}{*}{$\begin{array}{c}\begin{array}{c}\text { Standardized } \\
\text { Coefficients }\end{array} \\
\text { Beta }\end{array}$} & \multirow[b]{2}{*}{$\mathrm{t}$} & \multirow[b]{2}{*}{ Sig. } \\
\hline & & B & Std. Error & & & \\
\hline \multirow[t]{3}{*}{1} & (Constant) & -10.665 & 2.064 & & -5.168 & .000 \\
\hline & UNIT & .112 & .005 & 1.410 & 23.218 & .000 \\
\hline & JENIS & 8.037 & .992 & .492 & 8.102 & .000 \\
\hline
\end{tabular}

Berdasarkan tabel diatas dari hasil konstanta sebesar-10,665 ; koefisien unit estimasi regresi diperoleh koefisien kendaraan sebesar 0,112 dan koefisien 
jenis kendaraan sebesar 8,037 sehingga diperoleh persamaan regresi linier berganda sebagai berikut :

$$
\mathrm{Y}_{1}=-10,665+0,112 \mathrm{X} 1+8,037 \mathrm{X} 2
$$

Hasil regresi linier berganda pada analisis menggunakan variabel dependen BBM2 memberikan rumusan yang sama dengan BBM1.

Kemudian pada uji statistik t, tujuannya adalah untuk mengetahui apakah masing-masing variabel independen mempengaruhi variabel dependen secara signifikan. Hasil uji parsial $(\mathrm{t})$ dapat dilihat di tabel 4.

\section{Tabel 4}

Hasil Uji Parsial (t)

Coefficients $^{a}$

\begin{tabular}{llll}
\hline & & & \\
Model & $\mathrm{t}$ & Sig. & \\
\hline $1 \quad$ (Constant) & -5.168 & .000 \\
UNIT & 23.218 & .000 \\
JENIS & 8.102 & .000 \\
\hline
\end{tabular}

a. Dependent Variable: BBM1

Sumber : output SPSS

Dari tabel 4 maka diperoleh hasil uji statistik t sebagai berikut : Variabel Unit kendaraan (jumlah kendaraan), memperoleh t hitung sebesar 23,218 dan nilai signifikansi sebesar 0,000 . Karena nilai signifikansi lebih kecil dari 5\% maka $\mathrm{H} 0$ ditolak dan $\mathrm{H} 1$ diterima berarti terdapat pengaruh yang signifikan positif antara unit kendaraan dengan penggunaan (konsumsi) BBM baik untuk jarak terdekat maupun jarak terjauh. Hasil ini didukung oleh penelitian yang dilakukan oleh Handajani $\quad(2010,2011,2012) \quad$ suliyanti (2012), Andry Tanara (2003), Kerworthy and Fellix Laube (2002) yang menyatakan bahwa variabel unit kendaraan berpengaruh signifikan positif terhadap konsumsi BBM. Hasil yang signifikan positif menunjukkan bahwa peningkatan pada jumlah unit kendaraan akan meningkatkan penggunaan (konsumsi)
BBM. Setiap kendaraan akan membutuhkan BBM dalam menjalankan aktivitasnya dan semakin banyak jumlah unit kendaraan akan meningkatkan kebutuhan akan BBM.

Variabel Jenis Kendaraan, variabel ini dibagi menjadi dua jenis yaitu motor dan mobil. Dalam tabel menunjukkan $\mathrm{t}$ hitung sebesar 8,102 dengan nilai signifikansi sebesar 0,000 . Karena nilai signifikansi lebih kecil dari $5 \%$ maka $\mathrm{HO}$ ditolak dan $\mathrm{H} 2$ diterima berarti terdapat pengaruh yang signifikan positif antara jenis kendaraan dengan penggunaan (konsumsi) BBM baik untuk jarak terdekat maupun jarak terjauh. Hasil ini didukung oleh penelitian yang dilakukan oleh Handajani $(2011,2012)$ yang menyatakan bahwa variabel jenis kendaraan berpengaruh signifikan positif terhadap konsumsi BBM. Hasil yang signifikan 
positif menunjukkan bahwa peningkatan pada jenis kendaraan akan meningkatkan penggunaan (konsumsi) BBM. Setiap kendaraan yang dilihat dari jenisnya dibagi menjadi roda dua (motor) dan roda empat (mobil). Handajani (2012) menyatakan bahwa pertumbuhan pemilikan kendaraan bermotor didominasi oleh pertumbuhan kendaraan jenis sepeda motor.Dalam penelitian ini prosentase motor lebih banyak dari mobil namun kedua jenis ini sama-sama membutuhkan BBM dalam menjalankan aktivitasnya dan semakin banyak jenis kendaraan misalnya ditambah dengan angkutan barang, angkutan umum penumpang, bus, truk, dll tentunya akan meningkatkan kebutuhan akan BBM.

Dari Uji ketepatan perkiraan (Goodness of fit test), Uji ketepatan perkiraan (Goodness of Fit Test) bertujuan untuk menguji tingkat keeratan atau keterkaitan antara variabel dependen dengan variabel independent yang dapat dilihat dari besarnya nilai koefisien determinasi (Adjusted R-Square).

Tabel 5

\section{Hasil uji ketepatan perkiraan}

\begin{tabular}{|c|c|c|c|c|c|}
\hline \multicolumn{6}{|c|}{ Model Summary ${ }^{b}$} \\
\hline Model & $\mathrm{R}$ & R Square & $\begin{array}{l}\text { Adjusted R } \\
\text { Square }\end{array}$ & $\begin{array}{c}\text { Std. Error of the } \\
\text { Estimate }\end{array}$ & Durbin-Watson \\
\hline 1 & $.974^{\mathrm{a}}$ & .948 & .947 & 1.88934 & 1.823 \\
\hline \multicolumn{6}{|c|}{ a. Predictors: (Constant), JENIS, UNIT } \\
\hline \multicolumn{6}{|c|}{ b. Dependent Variable: BBM1 } \\
\hline \multicolumn{6}{|c|}{ Sumber : output SPSS } \\
\hline
\end{tabular}

Dari tabel diatas menunjukkan bahwa angka $\mathrm{R}$ sebesar 0,948 yang berarti bahwa korelasi atau hubungan antara variabel penggunaan (konsumsi) BBM dengan kedua variabel independennya adalah kuat. Sedangkan nilai Adjusted $R$-Square sebesar 0,947. hal ini berarti bahwa 94,7 persen variasi dari penggunaan (konsumsi) BBM bisa dijelaskan oleh variasi dari kedua variabel independen, sedangkan sisanya 5,3 persen dijelaskan oleh sebabsebab yang lain.
Dari Uji Beda T-Test, Uji beda ttest digunakan untuk menentukan apakah dua sample yang tidak berhubungan memiliki nilai rata-rata yang berbeda. Uji beda t-test dilakukan dengan cara membandingkan perbedaan antara dua nilai rata-rata dengan standar error dari perbedaan rata-rata dua sampel. 
Tabel 6

Group Statistics

Group Statistics

\begin{tabular}{|c|c|c|c|c|c|}
\hline & JENIS & $\mathrm{N}$ & Mean & Std. Deviation & Std. Error Mean \\
\hline \multirow[t]{2}{*}{ BBM1 } & 1.00 & 48 & 21.8854 & 5.53838 & .79940 \\
\hline & 2.00 & 52 & 8.6308 & 4.03133 & .55904 \\
\hline
\end{tabular}

Sumber : output SPSS

Dari tabel diatas terlihat bahwa rata-rata konsumsi BBM untuk Motor adalah 21,8854 liter dan untuk mobil adalah 8,6308 liter. Sehingga secara jelas bahwa rata-rata konsumsi $\mathrm{BBM}$ berbeda antara jenis kendaraan motor dan mobil, kemudian untuk mengetahui apakah perbedaan ini memang nyata secara statistik maka dapat melihat output kedua (independent sample test) pada tabel 7 dibawah ini

Tabel 7

Independent Sample Test

Independent Samples Test

\begin{tabular}{|c|c|c|c|c|c|c|c|c|}
\hline & $\begin{array}{l}\text { Levene's } \\
\text { Test for } \\
\text { Equality of } \\
\text { Variances }\end{array}$ & & & t-test & tor Equality & of Means & & \\
\hline & & & & & & & \multicolumn{2}{|c|}{$\begin{array}{l}95 \% \text { Confidence } \\
\text { Interval of the } \\
\text { Difference }\end{array}$} \\
\hline & F Sig. & $\mathrm{T}$ & $d f$ & $\begin{array}{l}\text { Sig. (2- } \\
\text { tailed) }\end{array}$ & $\begin{array}{c}\text { Mean } \\
\text { Difference }\end{array}$ & $\begin{array}{l}\text { Std. Error } \\
\text { Difference }\end{array}$ & Lower & Upper \\
\hline $\begin{array}{l}\text { BBM Equal } \\
1 \quad \begin{array}{l}\text { variances } \\
\text { assumed }\end{array}\end{array}$ & $\begin{array}{ll}4.987 & .028\end{array}$ & 13.758 & 98 & .000 & 13.25465 & .96344 & $\begin{array}{r}11.3427 \\
3\end{array}$ & 15.16656 \\
\hline $\begin{array}{l}\text { Equal } \\
\text { variances } \\
\text { not } \\
\text { assumed }\end{array}$ & & 13.588 & 85.392 & .000 & 13.25465 & .97548 & $\begin{array}{r}11.3152 \\
6\end{array}$ & 15.19404 \\
\hline
\end{tabular}

Sumber : Output SPSS

Dari tabel diatas, nilai $\mathrm{F}$ hitung levene test sebesar 4,987 dengan probabilitas 0,028 karena probabilitas $<0,05$ maka dapat disimpulkan bahwa $\mathrm{H} 0$ ditolak dan $\mathrm{H} 1$ diterima yang menunjukkan variance populasi konsumsi BBM antara motor dan mobil adalah berbeda. Dengan demikian analisis uji beda t-test harus menggunakan nilai t pada equal variances not assumed adalah 13,588 dengan probabilitas signifikansi 0,000 (two-tail). Sehingga kesimpulannya adalah rata-rata konsumsi BBM dalam liter berbeda secara signifikan antara jenis kendaraan motor dan mobil. 


\section{Kesimpulan Dan Saran \\ Kesimpulan}

1. Data jumlah kendaraan yang melintas di lingkungan kampus Undip Tembalang sebanyak 16.719 unit kendaraan komposisi 15.140 unit motor setara $90,56 \%$ dan 1.579 mobil setara $9,44 \%$ menunjukkan bahwa sebagian pesar pengguna kendaraan yang melintasi gerbang utama kampus Undip tembalang adalah kendaraan roda dua (motor). Potensi jumlah kendaraan ini tentunya akan meningkatkan permintaan akan bahan bakar minyak.

2 Potensi penggunaan (konsumsi) BBM di kampus Universitas Diponegoro Tembalang. Dimana konsumsi BBM mencapai 1987,7 liter untuk jarak terdekat dan 5331,5 liter untuk jarak terjauh dengan total biaya masing-masing 13 juta dan 35 juta. Proyeksi satu bulan kurang lebih mencapai 8000 liter untuk jarak terdekat dan 21.000 liter untuk jarak terjauh dengan total biaya masing-masing kurang lebih 52 juta dan 136,5 juta. Tentunya ini hanya mengakomodir satu jam tiap hari. Membuktikan bahwa kampus sebagai pusat peredaran uang yang sangat signifikan.

3. Tiga besar pengguna kendaraan yang melintas kampus Undip yaitu kode plat H, B dan K. Untuk plat H mencapai 7011 unit kendaraan setara $42 \%$, plat B mencapai 1618 unit kendaraan setara $10 \%$ dan plat $\mathrm{K}$ mencapai 1513 unit kendaraan setara $9 \%$. Menunjukkan hasil yang menarik bahwa pengguna kendaraan di lingkungan kampus Undip selain kode plat $\mathrm{H}$ ternyata untuk urutan kedua yaitu kode plat $\mathrm{B}$ mengalahkan kode plat $\mathrm{K}$, menunjukkan bahwa semakin meningkatnya pendatang dari kota besar seperti Jakarta khususnya mahasiswa untuk mengenyam pendidikan dibangku perkuliahan di kota Semarang. Tingginya minat orang tua yang menyekolahkan anak-anak mereka di kota Semarang karena biaya perkuliahan dan biaya hidup di kota Semarang lebih murah dibandingkan kota Jakarta dan sekitarnya.

4. Jumlah kendaraan berpengaruh signifikan positif terhadap penggunaan (konsumsi) BBM sehingga hipotesis $\mathrm{H} 1$ diterima. Kemudian variabel jenis kendaraan berpengaruh signifikan positif terhadap penggunaan (konsumsi) BBM sehingga hipotesis $\mathrm{H} 2$ diterima. Kedua variabel ini menunjukkan bahwa dengan semakin meningkatnya jumlah kendaraan dan jenis kendaraan akan meningkatkan penggunaan (konsumsi) BBM dilingkungan kampus Undip Tembalang.

5. Besarnya Adjusted R Square adalah 0,947 menunjukkan bawa 94,7 persen variasi dari penggunaan (konsumsi) BBM bisa dijelaskan oleh variasi dari kedua variabel independen yaitu jumlah kendaraan dan jenis kendaraan. Sisanya 5,3\% dipengaruhi faktor lain.

6. Dengan uji beda t-test maka ratarata konsumsi BBM dalam liter berbeda secara signifikan antara jenis kendaraan motor dan mobil. 
Saran

1. Penelitian ini memiliki keterbatasan antara lain sampel yang diambil hanya selama satu jam per hari disarankan untuk menambah periode pengamatan.

2. Untuk agenda penelitian mendatang akan lebih baik menggunakan variabel penelitian yaitu pola intesitas kendaraan, jenis BBM yang digunakan, umur kendaraan, perilaku pengguna jalan, kondisi jalan, harga BBM.

3. Bagi Kampus, peningkatan jumlah kendaraan yang signifikan disatu sisi akan meningkatkan permintaan terhadap BBM dan potensi biaya kebutuhan BBM akan tetapi memiliki efek negatif yaitu kemacetan dan polusi lingkungan.Oleh karena itu perlu adanya pengendalian jumlah konsumsi BBM dan pengendalian jumlah kendaraan dengan cara menekan jumlah kendaraan yang melintasi kampus, penyediaan fasilitas bus kampus, sepeda dan pejalan kaki yang lebih optimal.

\section{Daftar Pustaka}

Andry Tanara. 2003. Estimasi Permodelan Kebutuhan BBM untuk Transportasi Darat (Studi Kasus Palembang) Program Pascasarjana MSTTT, UGM, Yogyakarta

Departemen Perhubungan Darat. 2008. Perencanaan Umum Pengembangan Transportasi Massal di Pulau Jawa. Jakarta

Fatima DJ, Antonio. 2009. Analisis Optimalisasi Pengelolaan Aset Bergerak Pemerintah Timor Leste (Studi Kasus di Kementerian
Keuangan). Tesis. FEB UGM, Yogyakarta

Fikriah dan Oka Mahendra. Pengaruh Subsidi BBM terhadap Permintaan BBM Dalam Negeri.

Ghozali, Imam. 2006. Aplikasi Analisis Multivariate dengan Program SPSS. Badan Penerbit Universitas Diponegoro

Handajani, M. 2010. Analisis Pengaruh Struktur Kota-Sistem TransportasiKonsumsi BBM Kota-Kota di Jawa. Jurnal Teknik Sipil dan Perencanaan No. 2 Vol.12 Juli 2010 hal 101-110

Handajani, M. 2011. Model Pengaruh Sistem Transportasi Kota di Jawa Terhadap Konsumsi Bahan Bakar Minyak (BBM). Prosiding Konferensi Nasional Pascasarjana Teknik Sipil (KNPTS). 20 Desember 2011. ISSN 2089-3051

Handajani, M. 2012. Nonlinear Model Sistem Transportasi Pengendalian Konsumsi BBM Kota Sedang. Prosiding Seminar Nasional Jembatan Bentang Panjang Teknik Sipil USM 27 Juni 2012

Kenworthy J., and Fellix Laube. 2002. Urban Transport Pattern in a Global Sample of Cities and Their Linkages to Transport Infrastructure, Land-use, Economics and Environment. World Transport Policy and Practice Volume (8) Number (3) : 5-19 (3). ISSN 1352-7614

Mujiono. 2011. Susidized Fuel Consumption Monitoring System. Proceeding International Conference on Informatics for Development (ICID). UIN Sunan Kalijaga Yogyakarta, 26 November 2011 
Mujiono. 2012. Studi Awal Perkiraan Perilaku Konsumsi BBM Bersubsidi di Kabupaten/Kota Menggunakan Data Mining

Subsidi BBM pada APBN. Biro Analisa Anggaran dan Pelaksanaan APBN Setjen DPR RI.

Suliyanti, Rini, 2012. Evaluasi Faktor Peningkatan Konsumsi BBM Bersubsidi oleh Transportasi

Surminah, Iin, Manajemen Aset di Lembaga Litbang, PAPPIPTEKLIPI

T.F. Fwa. 2005. Sustainable Urban Transportation Planning and
Development Issues and Challenges for Singapore. Dept of Civil Engineering of Singapore.

Williams, HK, Bettner, Caecello. 2000. Financial and Managerial Accounting, Mc Graw-Hill International Edition

www.bps.go.id

www.dpr.go.id/setjen/biro-analisaapbn/apbn_Subsidi_BBM_dalam_r angka_RAPBNP_20122013013012 4147.pdf. (Diakses pada 19Februari 2013). 